\title{
PROTEASE EXTRACTION FROM SOIL BY SODIUM PYROPHOSPHATE AND CHEMICAL CHARACTERIZATION OF THE EXTRACTS
}

\author{
M. BONMATI, ${ }^{1 \star}$ B. CECCANTP and P. NANNIPIERP \\ >Dpt. Agronomía, Escola Universitaria d'Enginyeria Técnica Agrícola, Urgell 187, 08036 Barcelona, \\ Catalonia, Spain, Tstituto Chimica del Terreno, CNR, Via Corridoni 78, 56125 Pisa, Italy and \\ ${ }^{3}$ Dipartimento di Scienza del Suolo e Nutrizione della Pianta, Universitá degli Studi di Firenze, P.le \\ delle Cascine 28, 50144 Firenze, Italy
}

(Accepted 20 May 1998)

\begin{abstract}
Summary-Two arable soils and one pasture soil had previously been air-dried for $6 \mathrm{~d}$ and stored at room temperature. The enzyme activities remaining after this treatment were constant. The soils were then extracted with $140 \mathrm{mM}$ sodium pyrophosphate at $\mathrm{pH}$ 7.1. Amino acid $\mathrm{N}$ and total organic $\mathrm{C}$ contení of soils and soil extracts, together with humic and fulvic acids contení of soil extraéis were deter-mined. Total organic $\mathrm{C}$ was determined in soil residues obtained after extraction. Chemical characterization of the organic matter of soils, soil extracts and soil residues was carried out by pyrol-ysis-gas chromatography (Py-GC). Protease activity was determined in soil extracts and soil residues by using three different substrates: N-benzoyl-Largininamide (BAA), specific for trypsin; N-benzyloxy-carbonyl-L-phenylalanyl L-leucine (ZPL), specific for carboxypeptidases, and casein, essentially non-specific. Comparative studies between specific activities referred to organic $\mathrm{C}$ in soils, soil extracts and soil residues and their corresponding pyrogram composition, and also between total extracted or residual activity and the humine or unhumified organic matter contení of the corresponding soil, allowed us to establish hypotheses about the type of organic matter the enzymes are associated with. From $12 \%$ to $21 \%$ of the soil organic C (33\% to $39 \%$ of which were humic acids) and from $3 \%$ and $18 \%$ of amino acid $\mathrm{N}$ were extracted from soil using pyrophosphate. Py-GC analyses showed that pyrophosphate was effective in extracting condensed humic substances and glycoproteins and that the organic matter present in soil extracts was especially rich in intact or partially-decomposed fresh residues of carbohydrate origin and also in certain humus-associated proteins. Extracted BAA-hydrolysing activity accounted for $11 \%$ to $36 \%$ of the soil activity, depending on soil type. Extracted ZPL- and casein-hydrolysing activities were, with one exception, remarkably high, accounting for about $100 \%$ or even more of the soil activity, depending on soil type. According to the results BAA-hydrolysing proteases are probably mostly associated with highly condensed humus, ZPL-hydrolysing proteases with less condensed humic substances and casein-hydrolysing proteases with fresh organic matter. (๐ 1998 Published by Elsevier Science Ltd. All rights reserved.
\end{abstract}

*Author for correspondence. E-mail: bonmati@esab.upc.es 


\section{INTRODUCTION}

Active extracellular enzymes in soil may be associated with inorganic and organic colloids (Burns, 1982; Nannipieri et al, 1996). The amount of this extracellular enzyme activity may be indicative not only of the biological capacity of soil for the enzy-matic conversión of the substrate, which is independen! of the extant microbial activity, but it might also have an importan! role in the ecology of micro-organisms (Burns, 1982). There is the need to study the properties of naturally-occurring enzyme-or-ganic complexes present in soil. These complexes must be extracted in high yields before investi-gations on their activity and physical and chemical state.

Different hydrolases have been extracted from pasture or forest soils by salt solutions: $0.1 \mathrm{M}$ Tris-borate at $\mathrm{pH}$ 8.1, $0.1 \mathrm{M}$ Tris at pH 8.1, $0.1 \mathrm{M}$ Tris-citrate at pH 8.0 and $0.1 \mathrm{M}$ Tris-EDTA at pH 8.0 (Ladd, 1972); $0.2 \mathrm{M}$ phosphate-0.2 M EDTA buffer at pH 8.0 (Batistic et ai, 1980); $140 \mathrm{mM} \mathrm{Na} \mathrm{P}_{2} \mathrm{O}_{7}$ at about neutral pH (Nannipieri et ai, 1980). Cultivation did not consistently influence the contení or composition of soil peptides in molecular weight fractions of extracts obtained from two pod-zols using a mild extraction procedure (Warman and Isnor, 1991). Extracellular ¿3-glucosidases have been extracted from arable soils either by phos-phate-KCI-EDTA buffer at pH 7.0 (Hayano and Katami, 1977) or by $10 \mathrm{mM} \mathrm{Na}_{4} \mathrm{P}_{2} \mathrm{O}_{7}$ at pH 7.0-7.3 (Busto and Pérez-Mateos, 1995). Pyrophosphate was more effective than phosphate in extracting urease and amylase from different podzols (Nanniperi et al, 1975; Shcherbakova et al, 1981).

It was also demonstrated that $140 \mathrm{mM} \mathrm{Na4P207}$ at about neutral pH extracted extracellular urease from a podzol (Nannipieri et al, 1974). Ruggiero and Radogna (1984) reported that sodium pyropho-sphate was more efficient in extracting lacease from a forest soil than the phosphate-EDTA.

Mayaudon et al. (1975) and Batistic et al. (1980) suggested that extracted protease activities oceurred partly in soil as a carbohydrate-enzyme complex and partly as a humo-carbohydrate complex. Proteases have been extracted from arable soils by $0.1 \mathrm{M}$ Tris-borate at pH 8.1 (Ladd, 1972), $0.2 \mathrm{M}$ phosphate-0.2 M EDTA buffer at pH 8.0 (Mayaudon et al, 1975) and $0.1 \mathrm{M}$ phosphate at pH 7.0 (Hayano et al, 1987).

Proteases in soil play a role in $\mathrm{N}$ mineralization (Ladd and Jackson, 1982), a process regulating the amount of plant available N (Stevenson, 1986). Studies on the composition of protease-organic complexes in arable soils are important to deter $\neg$ mine the role of these biochemically-active organic fractions in soil fertility. More insights are required to know the chemical composition of organic mol-ecules extracted by Na4P207 under neutral con-ditions (Stevenson, 1982). This chemical characterization may give indications on the chemi-cal structure of matrices on which the extracted enzymes are associated. Proteases have been extracted by 50 mM Na4P207 at pH 9 from a mu $n$ nicipal solid waste compost (Rad et al, 1995) and also by 140 mM Na4P207 at $\mathrm{pH} 7.1$ from forest or permanent grassland soils (Nannipieri et al, 1980, 1982, 1985) but not from arable soils. The presence of humic molecules in pyrophosphate-extracted enzyme complexes from forest soils was demon-strated by pyrolysis-gas chromatography (Py-GC) (Ceccanti et al, 1986).

Our aims were: (1) to determine the efficacy of $140 \mathrm{mM} \mathrm{Na4P207}$ at pH 7.1 in extracting different proteases from two arable soils and one pasture soil; (2) to chemically characterize (amino acid $\mathrm{N}$ contení, fractionation in humic and fulvic acids, analysis by Py-GC) organic matter of soils, soil extraets and soil residues; (3) to compare the data obtained in Py-GC analysis and enzyme activity to find out the type of organic matter the proteases are associated with. Proteases were differentiated by assaying soil extraets and soil residues with different substrates as reported by Ladd and Butler (1972). To achieve our aims data obtained with soil extraets and residues were compared with those reported by Bonmatí (1989) in the same soils. 


\section{MATERIAL AND METHODS}

Site, soils and sampling

Three soils were selected among the most repre-sentative soil types of Catalonia and classified according to FAO-UNESCO (1974). Soil 5, a Calcaric Fluvisol, under maize (Zea mays)-rye grass (Lolium perenne) rotation, was sampled after cropping at Figueres (Alt Emporda); soil 13, a Calcaric Fluvisol, under tomato (Lycopersicon escu-lentum), was sampled after cropping, at Malgrat (Maresme); soil 19, a Dystric Cambisol, under permanent meadow, was sampled in winter at Viella (Valí d'Aran). Soils were collected (0 to $20 \mathrm{~cm})$ from 15-20 soil cores that were pooled together. The bulked samples $(1 \mathrm{~kg})$ were air-dried for $6 \mathrm{~d}$, sieved $(<2 \mathrm{~mm})$ and stored at room temperature for 3yr prior to investigation. Physico-chemical characteristics of the three soils are shown in Table 1 (from Bonmatí, 1989). Organic matter had been extracted with $0.1 \mathrm{M}$ sodium pyrophosphate-0.1 M NaOH (1/1) and fractionated into Humic acids, Fulvic acids, humine and unhumified organic matter, by using the method of Duchaufour and Jacquin (Pleven et al, 1967).

\section{Soil extraction and preparation of humic and fulvic acids}

Soils were extracted with $140 \mathrm{mM}$ sodium pyro-phosphate at $\mathrm{pH} 7.1$ (soil-solution ratio $1: 10$ ) at $37^{\circ} \mathrm{C}$ for 24 $\mathrm{h}$ in a shaking water bath. Before initi-ating the shaking process $\mathrm{N}_{2}$ was passed into the Erlenmeyer flasks containing the mixture and they were hermetically closed immediately afterwards. Centrifugation and bacteriological filtration were carried out as reported by Nannipieri et al. (1974). Soil extraets were exhaustively dialysed against water as reported by Ceccanti et al. (1978).

Table 1. Physico-chemical characteristics of soils

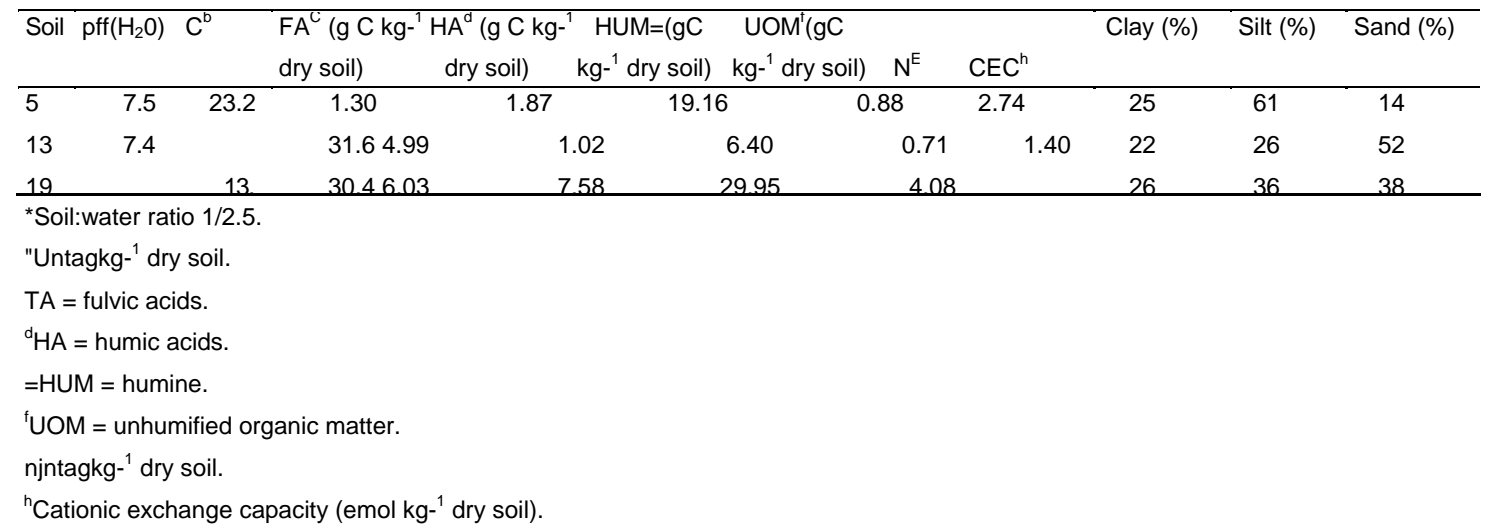

\section{Protease-organic complexes of arable soils}

Soil extraction was replicated at least three times.

Humic and fulvic acids were prepared from soil extracts as reported from Pujóla et al. (1990); $0.5 \mathrm{mi}$ of $2.5 \mathrm{M}$ $\mathrm{H} 2 \mathrm{~S} 04$ were added to $5 \mathrm{mi}$ of extract; trie mixture was left at $4^{\circ} \mathrm{C}$ for $24 \mathrm{~h}$ and then centrifuged ( $4000 \mathrm{xg}$, IOmin); the precipítate was washed with acidulated water and centrifuged.

\section{Amino acid $\mathrm{N}$ determination}

Amino acid $\mathrm{N}$ in soils and soil extracts was deter-mined as described by Stevenson (1982). Soil extracts were previously concentrated by ultrafiltra-tion (Amicon $202200 \mathrm{~cm} 3$ cell with a PM 10 diaflo-membrane) up to a total $\mathrm{N}$ contení of about $0.1 \mathrm{gl}$ "1. Three replicates were carried out. In the case of soil extracts each replication concerned a sepárate extraction from a new sample coming from the same bulked soil sample. The same procedure was followed for the rest of the determinations in soil extracts and soil residues in our work. Thus variability obtained for the results would include not only that of the analytical technique but also that of the 
extraction procedure.

\section{Organic $\mathrm{C}$ determination}

Total C and humic acids C of soil extracts were determined according to Pujóla et al. (1990). An excess of dichromate and $5 \mathrm{M} \mathrm{H} 2 \mathrm{~S} 04$ were added to the samples and then the organic $\mathrm{C}$ was oxidated by heating at $150^{\circ} \mathrm{C}$ for $15 \mathrm{~min}$; the mixtures were left for $24 \mathrm{~h}$ at room temperature and the formed $\mathrm{Cr} 3+$ determined by measuring the absorbance at $590 \mathrm{~nm}$ (Nikitin, 1972). Total $C$ of extraction resi-ndues was determinated by dichromate oxidation (Walkey, 1935). We performed at least three repli-cates for each sample. Each replication concerned, as reported for amino acid $\mathrm{N}$ determination, a sep aárate extraction from the same soil.

\section{Enzyme assays}

Total activities and specific activities referred either to organic $\mathrm{C}$ or amino acid $\mathrm{N}$ of soil extracts and soil residues were assayed using three different substrates: N-benzoyl-L-argininamide (BAA), Nbenzyloxycarbonyl-L-phenylalanyl-L-leucine (ZPL) and casein. N-benzoyl-L-argininamide hydrolysing activity of soil residues was determined as reported by Nannipieri et al. (1980); $1 \mathrm{~g}$ of residue was reacted for $1 \mathrm{~h}$ with $4 \mathrm{mi}$ of $7.5 \mathrm{mM}$ BAA dissolved in $0.1 \mathrm{M} \mathrm{pH} 7.1$ phosphate buffer; ammonium con-centration was determined by Orion Ammonium electrode. N-benzyloxycarbonyl-L-phenylalanyl-L-leucine-hydrolysing activity of soil residues was determined as reported by Ladd and Butler (1972); Ig of residue was reacted for Ih with 4 mi of $1 \mathrm{mM}$ ZPL dissolved in $0.1 \mathrm{M} \mathrm{pH} 8.1$ Tris-borate buffer; leucine concentration was determined by the ninhydrin reaction. Assays of these two activities

were performed at $40^{\circ} \mathrm{C}$ and replicated a minimum of three times, each replication concerning a differ $\neg$ ent extract from the same soil. Casein-hydrolysing activity of soil residues was determined as reported by Bonmatí et al. (1991) after four different incu-bation periods (1, 1.5, 2 and $3 \mathrm{~h}$ ); $1 \mathrm{~g}$ of residue was reacted at $51^{\circ} \mathrm{C}$ with $2.5 \mathrm{mi}$ of $1 \%$ casein dissolved in $0.1 \mathrm{M} \mathrm{pH} 8.1 \mathrm{Tris}-\mathrm{HCl}$ buffer; the concentration of trichloroacetic acid soluble peptides was colori-metrically determined by Folin reagent. Each assay concerned a sample coming from a different extract of the same soil. With the three assayed activities two types of control were carried out; buffer substi-tuted for the substrate solution in one control and no soil residue was present in the other.

Soil extracts were concentrated by ultrafiltration (as reported for the determination of amino acid $\mathrm{N}$ ) up to an organic C contení of $1 \mathrm{~g} \mathrm{P1}$ and then assayed for protease activities. The activities in the concentrated extracts (at least three replicates for each sample) were determined as follows:

BAA hydrolysis $0.6 \mathrm{mi}, 0.1 \mathrm{M} \mathrm{pH} 7.1$ phosphate buffer and $0.2 \mathrm{mi} 30 \mathrm{mM}$ BAA were added to $0.4 \mathrm{mi}$ of soil extract. Mixtures were reacted for $1 \mathrm{~h}$ at $40^{\circ} \mathrm{C}$ and then diluted with $15 \mathrm{mi}$ of distilled water. Ammonium concentration was determined by Orion ammonium electrode. In the control, the substrate solution independently incubated for $1 \mathrm{~h}$ at $40^{\circ} \mathrm{C}$, was added after diluting the mixture with water.

ZPL hydrolysis $0.6 \mathrm{mi}, 0.1 \mathrm{M} \mathrm{pH} 8.1$ Tris-borate buffer and $0.2 \mathrm{mi} 4 \mathrm{mM}$ ZPL were added to $0.4 \mathrm{mi}$ of soil extract. Mixtures were reacted for $1 \mathrm{~h}$ at $40^{\circ} \mathrm{C}$ and then diluted with $6 \mathrm{mi}$ of $2 \%$ ninhydrin reactive. Leucine concentration in mixtures was determined by the ninhydrin reaction. In the con $\neg$ trol, substrate solution independently incubated for $1 \mathrm{~h}$ at $40^{\circ} \mathrm{C}$, was added after diluting the mixture with ninhydrin.

Casein hydrolysis Soil extract ( $2 \mathrm{mi}$ ) was added to $2.5 \mathrm{mi}$ of $1 \%$ casein dissolved in $0.1 \mathrm{M} \mathrm{pH} 8.1 \mathrm{Tris}-\mathrm{HCl}$ buffer and reacted for $1,1.5,2$ and $3 \mathrm{~h}$ re-spectively at $51^{\circ} \mathrm{C}$. At the end of the reaction, $1 \mathrm{mi}$ of $17.5 \%$ trichloroacetic acid was added to precipíntate proteins and concentration of soluble peptides was colorimetrically determined by Folin's reagent. In the controls, substrate solutions independently incubated at $51{ }^{\circ} \mathrm{C}$ for the same time as reaction mixtures, were added after the trichloroacetic acid solution. Activity was determined by calculating the slope of the straight regression Une absorbance vs time, which was considered 
not to cross the origin of coordinates (Ladd and Butler, 1972).

Replications of activities of extracts concerned, as in their corresponding extraction residues, a differ $\neg$ ent extract from the same soil.

For all the activities that were determined (both in soil extracts and in soil residues), there was a lin $\neg$ ear relationship between the amount of formed pro duct and reaction time throughout the assay period; BAAhydrolysing activity was expressed in /¿mol N-NH4+ g"1 dry soil h"1, ZPL-hydrolysing activity in /¿mol leucine g"1 dry soil h"1 and casein-hydro-lysing activity in /¿mol tyrosine g"1 dry soil h"1.

Organic matter characterization by pyrofysis-gas chromatography-mass spectrometry (Py-GC-MS)

Soils, soil extracts and soil residues (two replíncales for each sample) were analysed by Py-GC-MS. Composite samples of soil extracts and soil residues were especially prepared for this technique by pooling together samples of at least three extrac-tions of the corresponding soil.

Py-GC was performed as reported by Alcafiiz et al. (1987a), with some modifications. Composite samples of soils and soil residues were finely pulver-ized and amounts of these samples equivalen! to $400 \mathrm{ng}$ of organic matter were introduced in pyrol-ysis quartz tubes as a water suspensión and dried with a rotatory procedure as reported by Gassiot-Matas et al. (1982). Composite samples of soil extracts were concentrated by ultrafiltration (as reported for the determination of amino acid N) up to an organic C contení of $6 \mathrm{~g} \mathrm{P1}$ and amounts of these samples equivalen! to $400 / \mathrm{xg}$ of organic mat $\neg$ ter were introduced in quartz tubes and dried as described before.

A CDS Pyroprobe 190 heated-filament with a platinum coil probé was used. Pyrolysis was carried out at $700^{\circ} \mathrm{C}$ for $10 \mathrm{~s}$, heating rate líTCras" 1 . The probé was coupled directly to a Hewlett-Packard HP-5995 A gaschromatograph with a fíame ioniz-ation detector. Separations were performed on a bonded phase capillary column (Supelcowax, Carbowax $20 \mathrm{M}$, Supelco, $25 \mathrm{~m}, 320$ /an) with a temperature program of $3 \mathrm{~min}$ at $60^{\circ} \mathrm{C}$ up to $240^{\circ} \mathrm{C}$ at $6^{\circ} \mathrm{C}$ per min. Injection was carried out using the splitless mode. Carrier gas was $\mathrm{He}$ at $1.5 \mathrm{mi}$ min"1. Mass spectra were obtained in a HP5995A quadru-pole mass spectrometer. The corresponding identifi-cations were performed by Py-GC-MS on a representative sample of each type, and extended to the others by coincidence on retention times.

To perform semi-quantitative comparisons between organic matter composition of samples, this procedure was followed.

- Among the 30 peaks which were identified by mass spectrometry, 18 were selected according to their frequency of occurrence and major relative área throughout the pyrograms, as well as taking into account, after consulting published data, the information they supplied on the samples organic matter composition. The mean peak áreas in the duplicated pyrograms were calculated and succes-sively normalized as a percentage of the sum of the 18 áreas; then the logarithm of each normalized área was calculated. The ulterior statistic process, according to the SPSS program (SPSS Inc., 1986), was performed by using the latter valúes.

- Correlation coefficients (SPSS-X 2.1-PEARSON COR) between pyrograms were calculated; then Multidimensional Scaling (MDS), based on the Euclidean Distance (SPSS-X 2.1-ALSCAL), was carried out according to Cuadras (1981). The data obtained were used to assess differences between pyrograms. This type of statistical treatment had been used before by Bonmatí et al. (1991) and proved to be a useful tool to study the overall differences among the samples investigated.

- Correlations between the área of peaks and Principal Components Analysis (PCA) based on the obtained correlation valúes were carried out (SPSS-X 2.1-FACTOR); interpretation was in accord with the conceptual approach of Gabriel (1971); the PCA treatment has been frequently utilized for in $\rightarrow$ terpretation of Py-MS data (Halma et ai, 1984; Alcafiiz et al, 1987b, 1994). Multivariant Regression, using the stepwise 
variable selection procedure, of every principal componen! and each peak (SPSS-X 2.1-REGRESSION) was calculated according to Cuadras (1981), so as to select the peaks being most responsible for the differences among pyrograms; Beck et al. (1997) used this ana-lytical system to find the most responsible factors for the variability in the results obtained when using different methods to measure soil microbial biomass. The two mentioned successive statistical analyses (PCA and Multivariant Regression) allowed us to reduce from 18 to 12 the number of Py-GC peaks being most responsible for the pyro $\mathrm{g}$ grams differences.

- The aforementioned pyrolysis producís were distributed into different families, according to the organic matter pool which they represented, by using the data obtained above as well as published data.

This distribution led to an interpretation of the differences among organic composition of tested samples.

Comparative studies between the enzyme activity and the organic matter composition of samples

Specific BAA-, ZPL- and casein-hydrolysing ac-tivities of soil extracts and soil residues were obtained. These activities were compared with those reported by Bonmatí (1989) of their corresponding soil. Soil, soil extract and soil residue specific activinties, referred to organic $C$, of each sample were also compared with their corresponding pyrogram com $\neg$ position. Finally total activities of the samples were obtained from among them and with the humine and unhumified organic matter contení of their cor $\neg$ responding soil. These procedures allowed us to confirm previously reported hypotheses, or to estab-lish new ones, on the composition of the protease-organic complexes.

Tahle 2. Organic carbón, humic acids (HA), fulvic acids (FA) and amino acid N contents of samples

\begin{tabular}{|c|c|c|c|c|c|c|c|}
\hline & \multirow[b]{4}{*}{ Sample } & \multicolumn{6}{|c|}{$\mathrm{g} \mathrm{C} \mathrm{kg-}^{1}$ dry residue (soil residues) or $\mathrm{g} \mathrm{kg-}^{1}$ dry } \\
\hline & & \multicolumn{3}{|c|}{ soil (soil extracts) } & \multicolumn{3}{|c|}{ mg amino acid $\mathrm{N} \mathrm{kg-}^{1}$ dry soil } \\
\hline & & & & conf. interval & & & conf. interval \\
\hline & & repliclate & mean & $P<0.05$ & replícate & mean & $P<0.05$ \\
\hline \multirow[t]{5}{*}{5} & soil & & & & 3 & 1600 & 180 \\
\hline & residue & 3 & 13.06 & 2.16 & & & \\
\hline & extract & 3 & 2.87 & 0.59 & 3 & 106 & 38 \\
\hline & HA in extract & 3 & 1.12 & 0.21 & & & \\
\hline & FA in extract & & 1.75 & 0.84 & & & \\
\hline \multirow[t]{5}{*}{13} & soil & & & & 3 & 1100 & 180 \\
\hline & residue & 3 & 9.22 & 2.19 & & & \\
\hline & extract & 4 & 1.80 & 0.52 & 3 & 36 & 7 \\
\hline & HA in extract & 3 & 0.59 & 0.21 & & & \\
\hline & FA in extract & & 1.21 & 0.27 & & & \\
\hline \multirow[t]{5}{*}{19} & soil & & & & 3 & 1950 & 90 \\
\hline & residue & 3 & 29.3 & 2.19 & & & \\
\hline & extract & 8 & 10.20 & 0.98 & 3 & 345 & 107 \\
\hline & HA in extract & 4 & 3.40 & 0.51 & & & \\
\hline & FA in extract & & 6.80 & 0.94 & & & \\
\hline
\end{tabular}




\section{RESULTS AND DISCUSSION}

The soils had an organic $\mathrm{C}$ contení ranging from 13 to $48 \mathrm{gkg} \sim 1$ and had been air-dried for $6 \mathrm{~d}$ before their storage at room temperature for $3 \mathrm{yr}$. The stability of the protease activities remaining after this treatment had been demonstrated by Bonmatí (1989).

\section{Extraction yields of organic $\mathrm{C}$ and amino acid $\mathrm{N}$}

Pyrophosphate was more effective in extracting organic $C$ than amino acid $N$ from soil (Table 2) thus confirming results reported by Stevenson (1982). As can be calculated from Tables 1 and 2, extraction yields of organic $C$ for soils 5,13 and 19 were $12 \%, 14 \%$ and 21\%, respectively, whereas those for amino acid $N$ were $7 \%, 3 \%$ and $18 \%$ of the respective total soil contents, which means that an important portion of the soil proteins and pep-tides are associated with pyrophosphate non-extrac-table organic matter. About $11 \%$ of organic C was extracted by phosphate-EDTA buffer from a fresh pasture soil (Batistic et ai, 1980). Percentages of or $\neg$ ganic $C$ and organic $N$ extracted by $140 \mathrm{mM} \mathrm{Na4P207}$ at pH 7.1 from two forest and one perma-nent grassland soil ranged from $11 \%$ to $43 \%$ and from $19 \%$ to $38 \%$ respectively (Nannipieri et al, 1980).

As can be verified by comparing the data in Tables 1 and 2, the extracted humic acids ranged from $45 \%$ to $60 \%$ of their amounts in soil. Sodium pyrophosphate being a mild extractant, is less effi-cient than the mixture

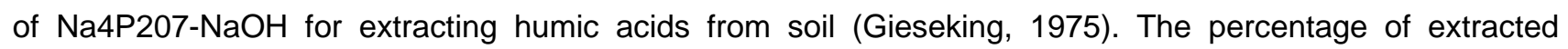
organic C contení pre $\neg$ sen! as humic acids ranged from 33\% to 39\% (data were calculated from Table 2).

Pyrogram characteristics and overall differences among soil and soil extract organic matter (MDS analysis)

As an example, Fig. 1 shows the pyrograms for soil 5 and its corresponding extract identifying the 18 chosen pyrolysis fragments and listing their cor-responding retention times. The normalized peak áreas in the whole of pyrograms are reported in Table 3.

Pyridine, pyrrole, 2-methyl-pyrrole, benzonitrile, p-toluenenitrile and Índole mainly proceed from the pyrolysis of polypeptides but partly also from the non-hydrolyzable nitrogen (Alcañiz et al, 1987a). Styrene and oxylene were obtained by the pyrolysis of proteins as well as from carbohydrates and from the aromatic fraction of humus, and they clearly increase during humification (Alcañiz et al, 1987a). Acetic acid, furfural, acetophenone and acetamide derive from the thermal degradation of carbo-hhydrates (Saiz-Jiménez et al, 1979; Irwin, 1982; Ceccanti et al, 1986; Alcañiz et al, 1987a). Guaiacol, ethylphenol and vynil-guaiacol are characteristic producís of the pyrolysis of lignins, which tend to decrease during humification (Bracewell et al., 1980b; Alcañiz et al, 1987a). Phenol and cresols have a less specific origin, being produced from humus, proteins and the pyrolytic cyclization of carbohydrates (Alcañiz et al, 1987a). The origin of cyclopentenone will be commented upon later.

The Multidimensional Scaling gave information about the composition of the organic matter extracted by pyrophosphate. The graphical distri-bution of pyrograms in two dimensions (Fig. 2) shows that the composition of each soil extract is very different from that of the relative soil; the most important differences (Table 3) can be resumed as follows: contributions by benzonitrile, 

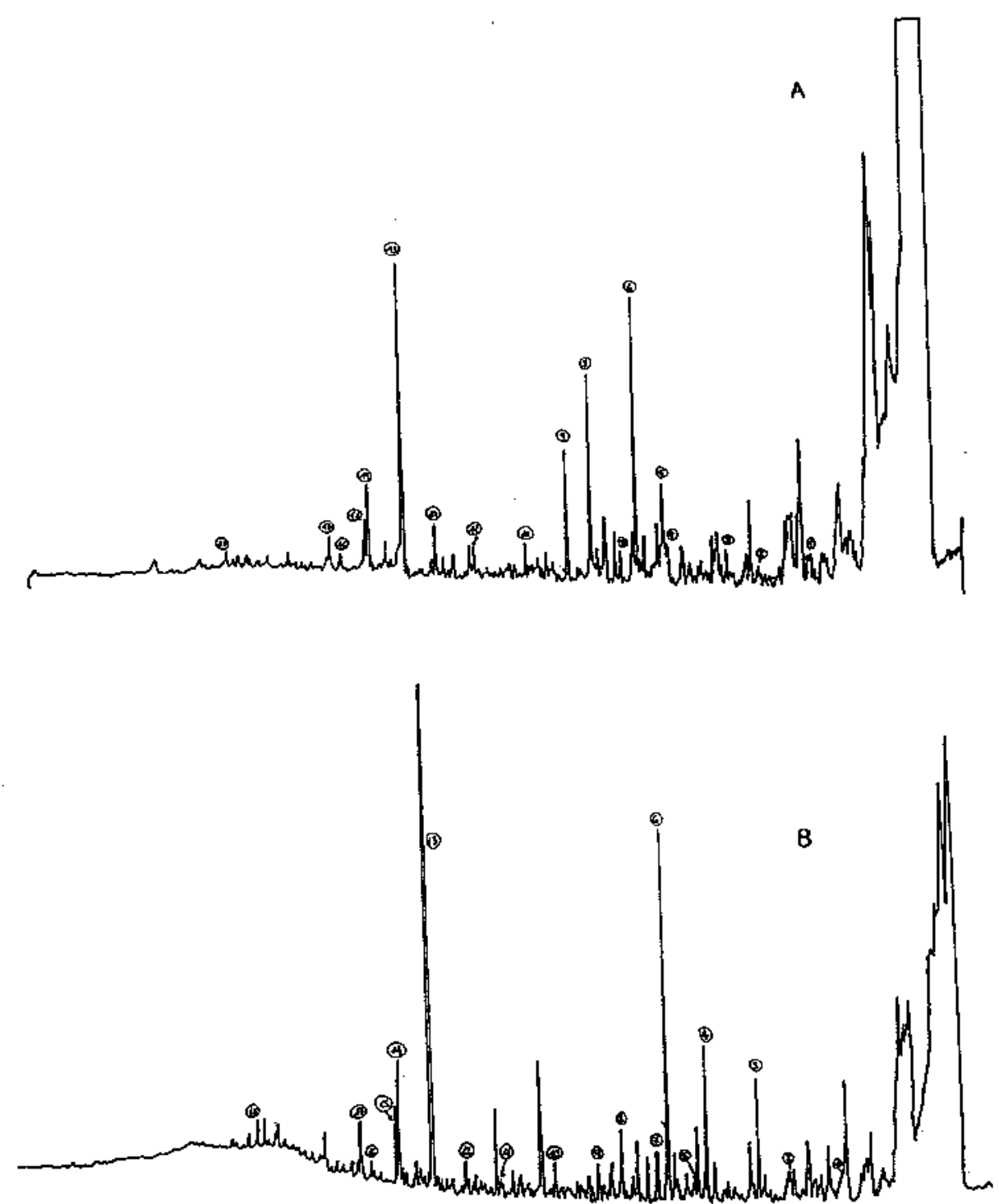

\begin{tabular}{|c|c|c|}
\hline Ref. n. & Pytolyets paoduet & Retentiont limen (minutes) \\
\hline 1 & Pyridine + o-xylone & 6.20 \\
\hline 2 & srysent & 8.17 \\
\hline 3 & Cyelopentenanes & 9.55 \\
\hline 4 & Aceric aeid & 11.40 \\
\hline 5 & Furtural & 1190 \\
\hline 6 & Pyrrofle & 12.91 \\
\hline 7 & 2-Mathyl-pincle & 13,77 \\
\hline 8 & Eenzoniltrile & 14.79 \\
\hline 9 & Aceiophenont & 15.73 \\
\hline 10 & Acetsmide & 28.14 \\
\hline 11 & Guatucal & 19.60 \\
\hline 12 & p-Talucbenitrile & 20.98 \\
\hline 13 & Phenol & 22.28 \\
\hline 14 & p-Cresal & 23.62 \\
\hline 15 & m-Cresal & $23 . \% 4$ \\
\hline 16 & Entyiphenad & 24.73 \\
\hline 17 & Vyyil-gosizod & 25.14 \\
\hline 18 & Indale & 29.24 \\
\hline
\end{tabular}




\begin{tabular}{|c|c|c|c|c|c|c|c|c|c|}
\hline Soil 5 & 3.65 & 2.62 & 1.16 & 0.34 & 9.29 & 18.82 & 2.72 & 11.24 & 9.16 \\
\hline Residue & 2.40 & 0.24 & 0.74 & 0.52 & 9.76 & 24.28 & 3.61 & 7.99 & 4.53 \\
\hline Extract & 0.18 & 0.60 & 0.36 & 13.26 & 0.54 & 18.86 & 2.39 & 3.07 & 2.35 \\
\hline Soil 13 & 1.63 & 1.44 & 0.61 & 0.24 & 6.23 & 13.88 & 0.64 & 42.29 & 11.40 \\
\hline Residue & 0.35 & 0.89 & 0.52 & 0.35 & 17.87 & 24.19 & 0.66 & 27.17 & 8.65 \\
\hline Extract & 7.35 & 0.12 & 7.36 & 16.67 & 5.15 & 16.70 & 2.91 & 2.83 & 0.67 \\
\hline Soil 19 & 12.35 & 7.21 & 5.74 & 8.32 & 4.86 & 11.72 & 2.22 & 6.58 & 2.79 \\
\hline Residue & 1.40 & 1.64 & 1.14 & 6.20 & 11.32 & 16.62 & 3.43 & 4.00 & 2.76 \\
\hline Extract & 0.09 & 4.99 & 0.61 & 14.13 & 3.24 & 16.01 & 2.32 & 3.20 & 1.96 \\
\hline Peaks & 10 & 11 & 12 & 13 & 14 & 15 & 16 & 17 & 18 \\
\hline
\end{tabular}

styrene and acetophenone were higher in soil pyro-grams, while those of acetic acid, derived from intact or partiallydecomposed fresh carbohydrates (Alcafiiz et al, 1987a), and phenol were higher in the pyrograms of soil extraéis. Thus a selective extractive action of pyrophosphate occurred. Carbohydrates, present in a high contení in soil extracts, play a role in stabilizing humus-enzyme complexes (Mayaudon et al, 1975).

Selection of the most responsible peaks for the differ-ences between pyrograms (PCA followed by Multi-variant Regression analyses)

The most importan! correlations between logaritmos of pyrogram peak áreas are given in Table 4 . There were significan! $(P<0.001$ or $P<0.01)$ and positive correlations among phenol, m-cresol and $p$-cresol; most of these phenolic derivatives were also positively correlated with some nitrogenated producís, especially 2-methylpyrrole and Índole, and with acetic acid, which derives from the thermal degradation of carbohydrates. A highly significan! $(P<$ 0.001) positive correlation was observed between acetophenone, also deriving from carbohydrates, and a nitrogenated product, benzonitrile. Cyclopentenone, deriving from both plant and mi-crobial aliphatic polycarboxylic acids (Alcafiiz et al, 1987a) and appearing in the pyrograms of humified soils (Bracewell et al, 1980a), was very significantly and positively correlated with pyridine plus o-xylene. Acetic acid was very significantly $(P<0.001)$ and negatively correlated with benzonitrile and with acetophenone; the same type of correlation was observed between benzonitrile and $m$-cresolor/>-cresol.

Table 5 shows the matrix for the five top factors in the principal components analysis explaining $91.5 \%$ of the total variation among logarithms of pyrogram peak áreas. The contributions to the total variation of factors 1 to 5 (data not shown) were $39.0 \%, 24.7 \%, 11.9 \%, 10.0 \%$ and 5.9\% respect-ively. Twelve peaks were the most representative of the overall variability among pyrograms when the multivariant regression of each of the five first factors and every peak was considered. The peaks were benzonitrile $(B)$, furfural $(F)$, guaiacol $(G)$, p-toluenenitrile $(T)$, acetamide $(A)$, vynilguaiacol $(V)$, p-cresol $(C)$, styrene $(S)$, cyclopentenone $(C Y)$, pyr-role $(P Y)$, pyridine + o-xylene $(P+X)$ and ethylphenol $(E)$. The mathematical expressions defining the relationship between the selected peak áreas and each five factors (I), as well as their corresponding $r^{2}$ and $P$ valúes, were the following (each letter means logarithm of the corresponding peak área):

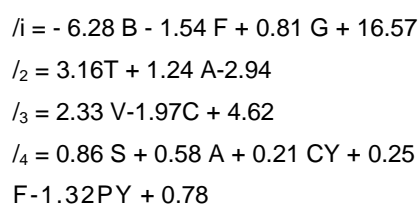


$f_{s}=-0.61 \mathrm{~A}+0.56(\mathrm{P}+\mathrm{X})+0.54 \quad r^{2}=0.9541, P=10 \sim^{4}$

$\mathrm{V}-0.55 \mathrm{E}+0.85$

By considering the correlation analysis and results reported by Irwin (1982), Ceccanti et al. (1986) and Alcañiz et al. $(1987 a, b)$ we have classi-fied the 12 peaks according to the type of organic matter which they represen!. Furfural, guaiacol, acetamide, vinyl-guaiacol and ethylphenol are sup-posed to derive from fresh organic matter while pyridine + o-xylene, cyclopentenone and styrene are the producís mainly representing the pyrolysis of the humified substances. Carbohydrate derivated pyrolysis producís are represented by furfural and acelamide while pyridine +0 -xylene, $1>-$ tolueneni- 


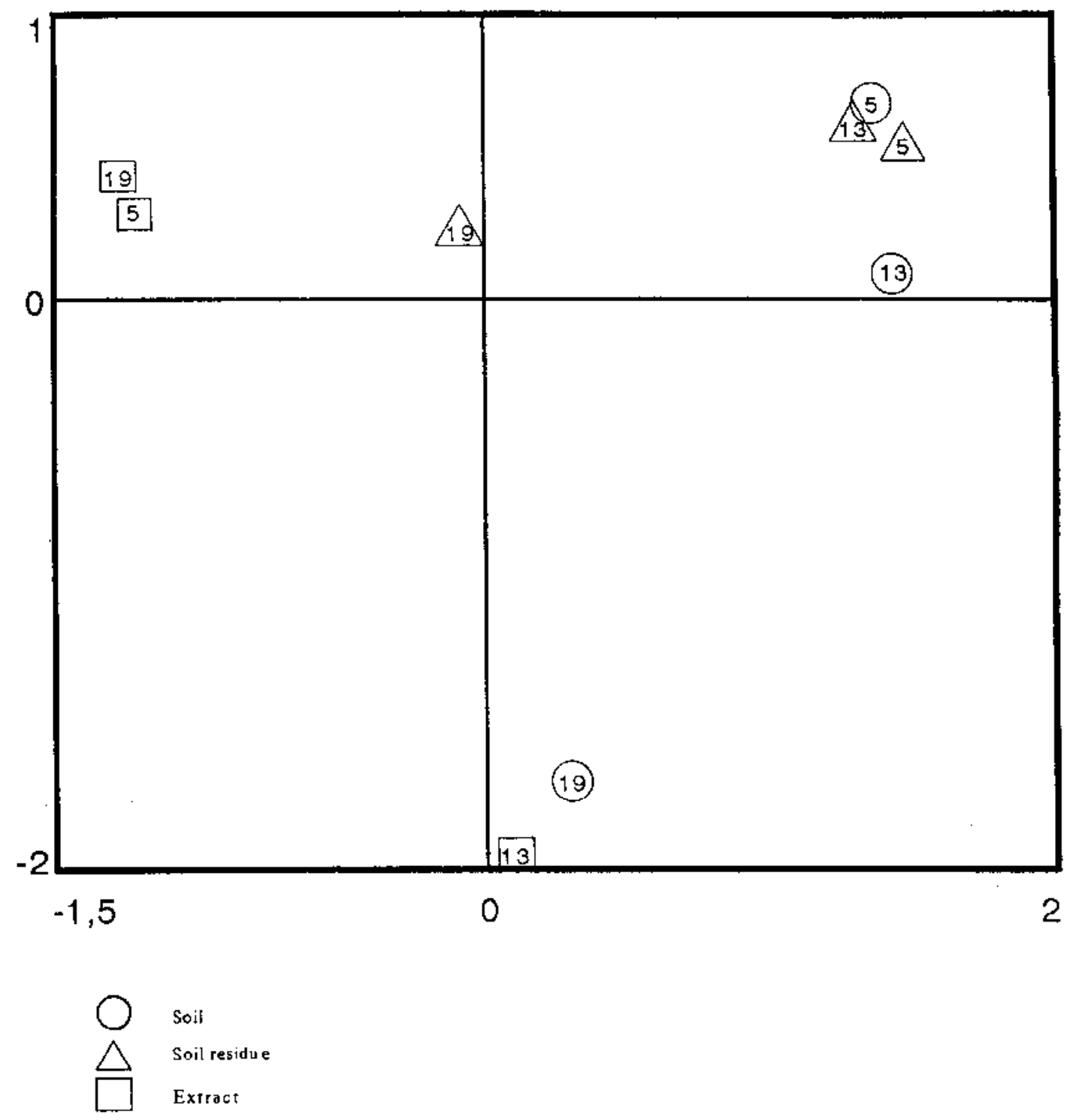

\begin{tabular}{cccc} 
STIMULUS & \multicolumn{3}{c}{ DIMENSION } \\
NUMBER & STIMULUS & 1 & 2 \\
1 & NAME & & \\
2 & $\log$ soil 5 & 1.3655 & 0.6808 \\
3 & $\log$ resid 5 & 1.4660 & 0.5413 \\
4 & $\log$ exir 5 & -1.2163 & 0.3085 \\
5 & $\log$ soll 13 & 1.4268 & 0.1020 \\
6 & $\log$ resid 13 & 1.3033 & 0.5960 \\
7 & $\log$ extr 13 & 0.1089 & -2.0322 \\
8 & $\log$ soil 19 & 0.2939 & -1.7011 \\
9 & $\log$ resid 19 & -0.0694 & 0.2320 \\
& $\log$ extr 19 & -1.2704 & 0.4295
\end{tabular}

Fig. 2. Graphical representation of the sample pyrograms in two dimensions according to Multidimensional Scaling 
Positive correlations

$P<0.001$

pyridine + o-xylene with cyclopentenone

henzonitrile with acetophenone

2-methyl-pyrrole with /7-cresol, m-cresol and

Índole

17-cresol with m-cresol

$P<0.01$ furfural with guaiacol

mcresol with acetic acid and phenol

pyridine + o-xylene with /7-toluenenitrile

phenol with /7-cresol

Índole with /7-cresol and m-cresol

Negative correlations

$P<0.001$

acetic acid with henzonitrile and acetophenone henzonitrile with m-cresol and /7-cresol henzonitrile with 2-methyl-pyrrole and

$P<0.005$ phenol acetophenone with $\mathrm{m}$-cresol

$P<0.01$

trile, pyrrole and p-cresol are derived from protein. Benzonitrile, highly positively correlated with acetophenone, has been chosen to represen! the pool of glycoproteins.

\section{Differences in the organic composition of samples}

According to the above classification five different organic matter pools were obtained by adding the normalized áreas of each peak in the pool considerad; Table 6 gives the corresponding valúes obtained in soils, soil extracts and soil residues. By comparing these valúes and the normalized áreas of the individual peaks constituting the pools (Table 3) it is confirmed that pyrophosphate selectively extracts humic molecules from soil. Indeed pyro-grams of soil residues have, compared with those of their relative soil, a lower proportion of humified organic matter derivatives (pyridine +0 -xylene, styrene and cyclopentenone) and a higher proportion of compounds deriving from fresh organic matter, particularly those (furfural, vynil-guaiacol and ethylphenol) deriving from ligno-cellulosic complexes (Alcafiiz et al., 1987a).

Pyrophosphate is also effective in extracting glycoproteins because the benzonitrile área is less in soil residues than in the unextracted soil. Some of these extracted glycoproteins may occur as enzyme complexes, in which the carbohydrate portion lacks enzyme properties but protects the catalytically-active components (Mayaudon, 1986).

Soil extracts were richer in pyrrole and p-cresol (both mainly derived from proteins) when their pyr-ograms were compared with those of the respective soil.

Enzyme activities of soil extracts and soil residues and their relationship with the organic matter composition

Total activities and specific activities referred either to organic $\mathrm{C}$ or amino acid $\mathrm{N}$ of soil extracts and soil residues are shown in Tables 7-9.

Recoveries of total activity in the extracts were almost $100 \%$ or higher for ZPL-hydrolysing activity in soils 13 and 19 (Table 8) and for casein-hydrolys-ing activity in the three soils (Table 9). In addition casein-hydrolysing activity of soil 5 residue was markedly higher than the respective activity of the unextracted soil (Table 9). Recoveries higher than $100 \%$ were found for casein-hydrolysing activities extracted by $140 \mathrm{mM} \mathrm{Na}_{4} \mathrm{P}_{2} \mathrm{O}_{7}$ at $\mathrm{pH} 7.1$ from a soil sampled under beechcoppice (Nannipieri et al, 1980) and for ZPL-hydrolysing activities extracted by $0.1 \mathrm{M}$ Tris-borate at pH 8.1 from a rendzina-pasture soil (Ladd, 1972). Recoveries were over 100\% when the latter activities extracted from the coarser fraction (1.0-2.0 mm) were compared with the unfractionated Chernozem-pasture soil (Ladd, 1972).

Regardless of the substrate used, the specific activities of soil extracts referred to amino acid $\mathrm{N}$ were higher than in soil, thus apparently indicating

Table 5. Matrix of the five top factors explaining $91.5 \%$ of the total variation among logarithms of the 18 most relevant pyrolysis frag-ments of soils, soil extracts and soil residues (Principal Components Analysis) 


\begin{tabular}{|c|c|c|c|c|c|}
\hline logofpeak $^{a}$ áreas & Factor 1 & Factor 2 & Factor 3 & Factor 4 & Factor 5 \\
\hline$\overline{\log l}$ & -0.25966 & 0.81073 & -0.31184 & 0.12747 & 0.32717 \\
\hline $\log 2$ & 0.13880 & -0.48437 & 0.40708 & 0.66041 & 0.17406 \\
\hline $\log 3$ & -0.13587 & 0.76398 & $-0.47583-$ & 0.16906 & 0.17879 \\
\hline $\log 4$ & 0.87133 & -0.24135 & ก วоววก & 0.17826 & -0.08616 \\
\hline $\log 5$ & $-0.58992-$ & $0.54630-$ & 0.03095 & $0.13097-$ & 014731 - \\
\hline $\log \frac{}{\log }$ & 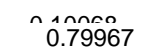 & $\begin{array}{c}\text { ก กาวกว } \\
0.53854\end{array}$ & $\begin{array}{l}\text { ก.ว7กกว } \\
0.17489\end{array}$ & $0.81930-$ & 0.10010 \\
\hline $\log 8$ & $-0.98037-$ & $0.00212-$ & 0.09247 & $0.07328-$ & 0.11774 \\
\hline loñ̂ & $\begin{array}{c}\text { n оากว1 } \\
0.26261\end{array}$ & $\begin{array}{c}\text { ก กาวго } \\
0.49303\end{array}$ & $\begin{array}{l}0.1<\Leftarrow n 1 \\
0.08767\end{array}$ & ก 0.543178 & $\begin{array}{r}n \text { ว51 } 16 \\
-0.57787\end{array}$ \\
\hline logll & $-0.43453-$ & 0.56004 & 0.56517 & 0.32628 & 0.06378 \\
\hline $\log 12$ & 011070 & 0.82980 & 0.16570 & $-0.27823-$ & 0.23035 \\
\hline $\log \mid 3$ & $\begin{array}{r}n .1670 \\
0.78271\end{array}$ & -0.42973 & 0.04197 & & 0.26021 \\
\hline $\log 14$ & 0.92190 & 0.21159 & 0.11326 & $0.07665-$ & 0.25795 \\
\hline $\log 15$ & 0.95575 & 0.19204 & 0.02792 & 0.04340 & 0.12598 \\
\hline logl6 & 0.38451 & 0.61429 & 0.38151 & -0.02641 & -0.37437 \\
\hline logl7 & 0.52204 & -0.03359 & 0.80329 & 0.05639 & 0.16193 \\
\hline logl8 & 0.66311 & 0.65494 & -0.06755 & -0.30500 & 0.00072 \\
\hline
\end{tabular}

${ }^{\mathrm{a}}$ See Fig. 1 for the peak identiflcation.

Tahle 6. Valúes of flve different organic matter pools for soils, soil extracts and soil residues, ohtained in each sample hy adding, within their corresponding pool, the áreas of the most responsihle peaks for the pyrograms differences

\begin{tabular}{|c|c|c|c|c|c|}
\hline \multicolumn{6}{|l|}{ Pools } \\
\hline $\begin{array}{l}\text { Py-GC producís } \\
\text { within the pool" }\end{array}$ & $\begin{array}{c}\text { Fresh organic matter } \\
5,10,11,16,17\end{array}$ & $\begin{array}{l}\text { Humifled organic } \\
\text { matter } 1,2,3\end{array}$ & Carhohydrates 5, 10 & Proteins $1,6,12,14$ & Glycoproteins 8 \\
\hline Soil 5 & 18.14 & 7.43 & 10.89 & 31.24 & 11.24 \\
\hline Residue & 20.69 & 3.38 & 12.29 & 37.74 & 7.99 \\
\hline Extract & 5.43 & 1.14 & 0.83 & 28.24 & 3.07 \\
\hline Soil 13 & 8.32 & 3.68 & 4.72 & 18.52 & 42.29 \\
\hline Residue & 21.55 & 1.76 & 18.87 & 26.91 & 27.17 \\
\hline Extract & 9.65 & 14.83 & 8.15 & 32.57 & 2.83 \\
\hline Soil 19 & 13.95 & 25.3 & 8.7 & 31.30 & 6.58 \\
\hline Residue & 22.86 & 4.18 & 14.36 & 28.23 & 4.0 \\
\hline $\mathrm{a}$ & & & & & \\
\hline Extract & 18.80 & 5.69 & 13.45 & 22.60 & 3.20 \\
\hline
\end{tabular}

a marked purification effect of the pyrophosphate extraction. Conformational changes in enzyme chains, including unmasking of the active size of these proteases, separation of inhibitors from enzymes or selective solubilization of proteases may occur during the extraction. Different humic sub-stances have an inhibitory action on protease activi-ties (Ladd and Butler, 1975).

Yields of total extracted BAA-hydrolysing activi-ties were always low, ranging from $11 \%$ to $36 \%$ (Table 7). Ladd (1972) obtained a low extraction yield for BAA-hydrolysing activity using 0.1 M Trisborate, $\mathrm{pH}$ 8.1, as a soil extractant. Low yields were also found in the extraction of these activities by pyrophosphate from a Mollisol and an Histosol but not in an Alfisol (Nannipieri et al, 1980). In addition Ladd and Paul (1973) found that BAA-hy-drolytic activity was relatively stable in soil. Since humine is not extracted by pyrophosphate (Stevenson, 1982) it is reasonable to hypothesize that most of BAAhydrolysing activity is associated with humine. Indeed, a significant and positive $(P<0.001)$ correlation was found between this enzyme activity and the humine contení of soil (Bonmatí, 1989). On the other hand BAA-hydrolys $\neg$ ing activities of soil residues and also their specific activities referred to the organic $C$ contení were lower than those of the corresponding soil (Table 7). If BAAhydrolysing activity was mostly associated

with humine, the low activity found in the soil resi-dues could be explained by the mechanical disintegration of sodium pyrophosphate over the humine-enzyme complexes during the extraction (Ceccanti et al, 1982, 1986). This action would sepárate some of these complexes bound through electrostatic 
bonds, rendering the enzymes unprotected and henee susceptible to proteolysis.

Casein- and ZPL-hydrolysing specific activities of soil extracts and soil residues were, with the exception of the ZPL-hydrolysing activity of the soil 19 residue, higher than those of the corresponding unextracted soils (Tables 9 and 8 , respectively). The most marked enhancements were for the ZPLhydrolysing activity of soil 13 extract and for the casein-hydrolysing activity of soil 5 residue.

The pyrogram of soil 13 extract had a higher pro-portion of pyridine +0 -xylene and cyclopentenone than the pyrogram of the respective soil, whereas pyrograms of the other two soil extracts showed lower proportion of these compounds than the re $\neg$ spective soil pyrograms (Table 3). Indeed soil 13 extract contained more humified organic matter and proteins than the respective soil; the reverse was true for the other two soil extracts (Table 6). The comparison of the same peaks in the pyrograms (Table 3) may also explain why ZPL-hydrolysing specific activity was low in soil 19 residue, in whose pyrogram the proportions of pyridine + o-xylene

Table 7. BAA-hydrolysing activities of soils (S) soil extracts (E) and soil residues (RES)

Units*

\begin{tabular}{llll} 
Sample & & & \\
\cline { 1 - 2 } & & & \\
S5 $^{\mathrm{d}}$ & 3 & 2.153 & Recovery" (\%) \\
E5 & 3 & 0.237 & \\
RES5 & 3 & 0.209 & 11 \\
S13 $^{\mathrm{d}}$ & 3 & 0.966 & 10 \\
EI 3 & 4 & 0.113 & \\
RES13 & 5 & 0.452 & 12 \\
S19 & 3 & 2.988 & 47 \\
E19 & 4 & 1.080 & \\
RES19 & 6 & 0.821 & 36 \\
\cline { 1 - 2 } & & & 27
\end{tabular}

conf. interval of $x(P<0.05)$

0.3710 .0710 .0630 .1930 .0290 .1130 .7450 .3520 .258

*BAA-hydrolysing activity (fimol N-NH${ }_{4}^{+} \mathrm{g}-{ }^{1}$ dry soil $\mathrm{Ir}^{1}$ ).

${ }^{b}$ Recovery: percent activity calculated with résped to that of the corresponding soil.

${ }^{c} x=$ mean.

'Data ohtained from Bonmatí (1989).

and cyclopentenone were $89 \%$ and $80 \%$ respect-ively, less than in the corresponding soil, whereas in the soil and soil residue pyrograms of samples 5 and 13 these ratios were only 1.5 and 4.5 and 1.6 and 1.2, respectively. It can be concluded that ZPL-hydrolysing activity is probably associated with the humified material represented by pyridine +0 -xylene and cyclopentenone in the pyrograms.

In the case of soil 5 residue (Table 3) the peak of styrene in the pyrogram of this sample was $9 \%$ of its corresponding unextracted soil, whereas in the soil and soil residue pyrograms of samples 13 and 19 these same ratios were $60 \%$ and $25 \%$, respect-ively. This much lower styrene contení mainly explains the lower humified organic matter contení of the soil residue when compared with the relative unextracted soil in sample 5 (Table 6). Probably the humified organic matter represented by styrene as pyrolytic product has a negative influence on the casein-hydrolysing activity and this may explain the high activity of the soil 5 residue. Bonding of the protease to humus might protect the enzyme pro-tein against proteolysis but might also render it in $\neg$ accesible and thus inactive towards substrates of high molecular weight such as casein (Rowell et al., 1973). This hypothesis was also supported by the fact that, as commented before, soil residues (with higher specific 
caseinolytic activity than their rela-

tive soils) have a lower proportion of humified or $n g a n i c$ matter and a higher proportion of fresh organic matter derivatives than their corresponding soils. Casein-hydrolysing activity was found signifi-cantly and positively correlated $(P<0.001)$ with the unhumified organic matter contení of soils (Bonmatí, 1989).

In conclusión our results prove that pyropho-sphate is an efficient extractan! of protease-humic complexes, including those containing glyco-proteins, from arable soils and that the extracted organic matter is especially rich in intact or par-tially-decomposed carbohydrates. Comparison of data obtained in Py-GC analyses and in protease activities confirmed that BAA-hydrolysing proteases are generally associated with highly condensed humic matter, while ZPL-hydrolysing proteases are probably associated with less-condensed humic ma-terial. Casein-hydrolysing proteases are generally as $\neg$ sociated with non-humified organic matter. Further studies are in progress to characterize the organic-proteases complexes extracted from arable and pas-ture soils. The studies include molecular weight fractionation of extracts and characterization of the relative fractions by the same techniques used in the present work and also by isoelectric focusing. The derivative fractions will be also characterized for

Table 9. Casein-hydrolysing activities of soils (S) soil extracts (E) and soil residues (RES)

\begin{tabular}{|c|c|c|c|c|c|c|}
\hline \multirow[b]{2}{*}{ Sample } & \multicolumn{3}{|r|}{ Units* } & \multicolumn{3}{|r|}{ Units fig- ${ }^{1}$ amino } \\
\hline & & & conf. interval of $x(P<0.05)$ & \multirow[t]{2}{*}{ Recovery" (\%) } & \multirow{2}{*}{$\begin{array}{l}x \\
9\end{array}$} & \multirow{2}{*}{$\begin{array}{c}x \\
124\end{array}$} \\
\hline $\mathrm{S} 5^{3}$ & 7 & 0.199 & 0.02 & & & \\
\hline E5 & 4 & 0.248 & & 125 & 86 & 2330 \\
\hline RES5 & 4 & 1.929 & 2 & 969 & 145 & ND \\
\hline $\mathrm{S} 13^{3}$ & 6 & 0.163 & 0.07 & & 12 & 150 \\
\hline El 3 & 4 & 0.164 & 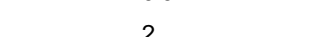 & 101 & 91 & 4470 \\
\hline RES13 & 4 & 0.163 & 2 & 100 & 18 & ND \\
\hline $\mathrm{S} 19^{3}$ & 7 & 0.605 & 0.27 & & 13 & 310 \\
\hline E19 & 4 & 0.543 & 0 & 90 & 53 & 1570 \\
\hline \multirow[t]{13}{*}{ RES19 } & 4 & 0.531 & 9 & 88 & 18 & ND \\
\hline & & & 0.03 & & & \\
\hline & & & 5 & & & \\
\hline & & & 0.03 & & & \\
\hline & & & 8 & & & \\
\hline & & & 0.08 & & & \\
\hline & & & 2 & & & \\
\hline & & & 0.03 & & & \\
\hline & & & 0 & & & \\
\hline & & & 0.14 & & & \\
\hline & & & 2 & & & \\
\hline & & & 0.16 & & & \\
\hline & & & 3 & & & \\
\hline \multicolumn{7}{|c|}{ Casein-hydrolysing activity (fimol tyrosine $\mathrm{g}^{-1}$ dry soil $\mid \mathrm{rr}^{1}$ ). } \\
\hline \multicolumn{7}{|c|}{${ }^{\mathrm{b}}$ Recovery: percent activity calculated with résped to that of the corresponding soil. } \\
\hline${ }^{c} x=m e$ & & & & & & \\
\hline
\end{tabular}


their thermal stability and optimal $\mathrm{pH}$ and tempera-ture valúes.

Acknowledgements-We wish to express our gratítude to Professor J. M. Alcañiz (CREAF Universitat Autónoma, Barcelona) and Professor L. Cornelias and his staff (CETS Instituí Químic de Sarria, Universitat Ramón Llull, Barcelona) for their assistance in the performing and in $\neg$ terpretaran of pyrograms, to Professor J. Valero (Rural Engineering Department, Escola d'Agricultura, Barcelona) for his assistance in the statistical analysis of data, to Professor S. Rehecho (Agronomy Department, Escola d'Agricultura, Barcelona) for revising the English versión and to K. Torla (Computing Centre, Escola d'Agricultura, Barcelona) for her assistance in data processing. The work was partially supported by the CIRIT of the Autonomus Goverment of Catalonia.

\section{REFERENCES}

Alcañiz J. M., Cabeza L., Cornelias L., Gassiot-Matas M. and Seres A. (1987a) Comparative identification of py-rolysis producís from soil organic matter and some plant debris. In Current Perspectives in Environmental Biogeochemistry, eds. G. Giovannozzi-Sermani and P. Nannipieri, pp. 35-46. CNR-IPRA, Roma.

Alcañiz J. M., Seres A., Gassiot M., Cabeza L. and Cornelias L. (1987b) A multifactorial analysis of soil pyrograms as a criterion for discrimination between humus types. The Science of Total Environment 62, 97106.

Alcañiz J. M., Granada E. and Cornelias L. (1994) Simulating the effects of burning on soil organic matter in a forest soil studied by pyrolysis gas chromatography. In Humic Substances in the Global Environment and Implications on Human Health, eds. N. Senesi and T. M. Miaño, pp. 205-212. Elsevier, Amsterdam.

Batistic L., Sarkar J. M. and Mayaudon J. (1980) Extraction, purification and properties of soil hydro-lases. Soil Biology \& Biochemistry 12, 59-63.

Beck T., Joergensen R. G., Kandeler E., Makeschin F., Nuss E., Oberholzer H. R. and Scheu S. (1997) An inter-laboratory comparison of ten different ways of measuring soil microbial biomass C. Soil Biology \& Biochemistry 29, 1023-1032.

Bonmatí M. (1989) Les proteases estabilitzades i la seva relació amb la materia orgánica en els sois agrícoles. Arxius Escola Superior d'Agricultura 12, 55-70.

Bonmatí M., Ceccanti B. and Nanniperi P. (1991) Spatial variability of phosphatase, urease, protease, organic car $\neg$ bón and total nitrogen in soil. Soil Biology \& Biochemistry 23, 391-396.

Bracewell J. M., Roberston G. W. and Welch D. I. (1980a) Polycarboxylic acids as the origin of some pyrolysis pro $\neg$ ducís characteristic of soil organic matter. Journal of Analytical and Applied Pyrolysis 2, 239248.

Bracewell J. M., Roberston G. W. and Williams B. L. (1980b) Pyrolysis-mass spectrometry studies of humification in a peat and a peaty podzol. Journal of Analytical and Applied Pyrolysis 2, 53-62.

Burns R. G. (1982) Enzyme activity in soil: location and a possible role in microbial ecology. Soil Biology \& Biochemistry 14, 423-427.

Busto M. D. and Pérez-Mateos M. (1995) Extraction of humic jS-glucosidase fractions from soil. Biology and Fertility of Soils 20, 77-82.

Ceccanti B., Nannipieri P., Cervelli S. and Sequi P. (1978) Fractionation of humus-urease complex. Soil Biology \& Biochemistry 10, 39-45.

Ceccanti B., Bertolucci M. T. and Rustighi G. (1982) Isoelectric focusing: un método efficace per la caratteri- zacione dell'umus del terreno. L'agricoltura Italiana 111, 179-185. 
Ceccanti B., Alcañiz J. M., Gispert M. and Gassiot M. (1986) Characterization of organic matter from two different soils by pyrolysis-gas chromatography and iso-electric focusing. Soil Science 142, 83-90.

Cuadras C. M. (1981) In Métodos de Análisis Multivariante, pp. 269-292. Eunibar, Barcelona.

FAO-UNESCO (1974) Soil Map of the World (1:5000000). UNESCO, París.

Gabriel K. R. (1971) The biplot graphic display of matrices with application to principal component analyses. Biometrika 58, 453-467.

Gassiot-Matas M., Alcañiz J. M. and Andrés J. (1982) Pyrolysis-gas chromatography-mass spectrometry of a low organic matter calcareous soil. Journal of Analytical and Applied Pyrolysis 4, 241-256.

Gieseking J. E. (1975) Soil Components, I. Organic Components. Springer, New York.

Halma G., Vam D., Haverkamp J., Winding W. and Meuzelaar H. L. C. (1984) Characterization of an oligotrophic-eutrophic peat sequence by pyrolysis-mass spec-trometry and conventional analytical methods. Journal of Analytical and Applied Pyrolysis 7, 167-184.

Hayano K. and Katami A. (1977) Extraction of jS-glucosi-dase activity from pea field soil. Soil Biology \& Biochemistry 9, 349-351.

Hayano K., Takeuchi M. and Ichishima E. (1987) Characterization of a metalloproteinase component extracted from soil. Biology and Fertility of Soils 4, 179-183.

Irwin W. J. (1982) Analytical Pyrolysis: a Comprehensive Guide. Marcel Dekker, New York.

Ladd J. N. (1972) Properties of proteolithic enzymes extracted from soil. Soil Biology \& Biochemistry 4, 227239.

Ladd J. N. and Butler J. H. (1972) Short-term assays of soil proteolytic enzyme activities using proteins and dipeptide derivatives as substrates. Soil Biology \& Biochemistry 4, 19-30.

Ladd J. N. and Butler J. H. (1975) Humus-enzyme sys-tems and synthetic, organic polymer-enzyme analogs. In Soil Biochemistry, Vol. 4, eds. E. A. Paul and A. D. McLaren, pp. 143-194. Academic Press, New York.

Ladd J. N. and Jackson R. B. (1982) Biochemistry of ammonification. In Nitrogen in Agricultura! Soils, ed. F. J. Stevenson, pp. 173-228. American Society of Agronomy, Madison, WI.

Ladd J. N. and Paul E. A. (1973) Changes in enzymic ac $\neg$ tivity and distribution of acid soluble, amino acid nitro-gen in soil during nitrogen immobilization. Soil Biology \& Biochemistry 5, 825-840.

Mayaudon J. (1986) The role of carbohydrates in the free enzymes in soil. In Peat and Water, ed. C. H. Fuchsman, pp. 263-309. Elsevier, Amsterdam.

Mayaudon L, Batistic L. and Sarkar J. M. (1975) Proprietés des activités proteolitiques extraites des sois frais. Soil Biology \& Biochemistry 7, 281-286.

Nannipieri P., Ceccanti B., Cervelli S. and Sequi P. (1974) Use of $0.1 \mathrm{M}$ pyrophosphate to extract urease from a podzol. Soil Biology \& Biochemistry 6, 359-362.

Nanniperi P., Cervelli S. and Pedrazzini F. (1975) Concerning the extraction of enzymatically active or $\neg$ ganic matter from soil. Experientia 31, 513-514.

Nannipieri P., Ceccanti B., Cervelli S. and Matarese E. (1980) Extraction of phosphatase, urease, proteases, organic carbón, and nitrogen from soil. Soil Science Society of America Journal 44, 1011-1016. Nannipieri P., Ceccanti B., Conti C. and Bianchi D. (1982) Hydrolases extracted from soil: their properties and ac-tivities. Soil Biology \& Biochemistry 14, 257-263. 
Nannipieri P., Ceccanti B., Bianchi D. and Bonmatí M. (1985) Fractionation of hydrolase-humus compexes by gel chromatography. Biology and Fertility of Soils 1, 25-29.

Nannipieri P., Sequi P. and Fusi P. (1996) Humus and enzyme activity. In Humic Substances in Terrestrial Ecosystems, ed. A. Piccolo, pp. 293-328. Elsevier, Amsterdam.

Nikitin B. (1972) Methods for determining the humus con`tení of soil. Agrokhimiya 3, 123-125.

Pleven J., Schmeltz C. and Righi D. (1967) Method of P. Duchaufour and J. Jacquin for the extraction and separ-ation of humic compounds. Bulletin de l'Association Franqaise d'Etude du Sol 6, 15-25.

Pujóla M., Saña J., Balanyá T. and Romero del Castillo R. (1990) Efectos de los fangos de depuradoras de aguas residuales urbanas sobre la fracción húmica de suelos agrícolas. Actas del I Congreso Internacional de Química de la Anque 1, 151-159.

Rad J. C, Navarro-González M. and González-Carcedo S. (1995) Characterization of proteases extracted from a compost of municipal solid wastes. Geomicrobiology Journal 13, 45-56.

Rowell M. J., Ladd J. N. and Paul E. A. (1973) Enzymatically active complexes of proteases and humic acid analogues. Soil Biology \& Biochemistry 5, 699-703.

Ruggiero P. and Radogna V. M. (1984) Properties of lac $\neg$ ease in humus-enzyme complexes. Soil Science 138, 74-87.

Saiz-Jiménez C, Haider K. and Meuzelaar H. L. C. (1979) Comparisons of soil organic matter and its fractions by pyrolysis mass-spectrometry. Geoderma 22, 25-37.

Shcherbakova T. A., Mas'ko A. A. and Galushko V. F. (1981) Extraction of órgano-mineral complexes with enzymatic activity from soils. Soviet Soil Science (English translation) 13, 45-52.

SPSS Inc. (1986) SPSS User's Guide, Versión 2. McGraw-Hill, New York.

Stevenson F. J. (1982) Nitrogen-organic forms. In Methods of Soil Analysis, Part 2. Chemical and Microbiological Properties, eds. A. L. Page, R. H. Miller and D. R. Keeney, 2nd edition, pp. 625-641. American Society of Agronomy, Madison.

Stevenson F. J. (1986) Cycles of Soil Carbón, Nitrogen, Phosphorus, Sulfur, Micronutrients. Wiley, New York.

Walkey A. (1935) An examination of methods for deterᄀmining organic carbón and nitrogen in soils. Journal of Agricultural Science 25, 598-609.

Warman P. R. and Isnor R. A. (1991) Amino acid compo-sition of peptides present in organic matter fractions of sandy loam soils. Soil Science 152, 7-13. 


